\title{
THE CHARTER OF THE UNITED NATIONS AND INSTITUTIONAL SYSTEM FOR THE PROMOTION AND PROTECTION OF HUMAN RIGHTS
}

\author{
T. Tănăsescu
}

\section{Tudor Tănăsescu}

Law Faculty, „Bioterra” University from Bucharest, Ramania

Correspondence: Tudor Tănăsescu, str. Pescăruşului nr.3, Bl. B-24, Sc.3, Et. 6, Ap.145, Sector 2, Bucureşti, România.

E-mail: tanasescutudor@yahoo.com

\section{Abstract}

Institutional system for the promotion and protection of human rights was established by the Charter of the United Nations and on its basis thereof is part of the category of monitoring mechanisms, promotion and protection of human rights to universal level. This, together with the mechanisms carried out on the basis of conventions O. N. U. relating to human rights, has an important role in the surveillance promotion and protection of human rights and, by default, in implementing the provisions as regards international regulations in this matter.

To promote and encourage respect for human rights and fundamental freedoms, the United Nations uses its subsidiary bodies, entities that have specific powers on the area referred to.

Key words: Charter of the United Nations, Institutional system, protection, human rights, mechanisms.

\section{Introduction}

For the purposes of supervision and application of U.N.conventions relating to human rights have been created distinct mechanisms, most of which, in fact, carried out under the provisions of conventions concerned. Also, along with these was carried out by the Charter of U.N. and in its basis an institutional system that can have an important role in promoting and monitoring protection of human rights and, by default, in the implementation of international regulations implement the provisions aimed this problem ${ }^{1}$.

The institutional framework for the promotion and protection of human rights established by the Charter of U.N. adopted on 26 June 1945 and entered into force on 24 October 1945 (document by which it is fully constituted the United Nations), belongs to the category of monitoring mechanisms, Promotion and protection of human rights to universal level.

Article 1 of the Charter indicates right end of the U.N. "achieving international cooperation in promoting and encouraging respect for human rights and for fundamental freedoms for all without distinction as to race, sex, language or religion".

In addition, in Article $55 \mathrm{c}$ ) of the Charter shall be stated that the United Nations will foster effective and universal respect of human rights.

For the proper functioning of the U.N., in accordance with the provisions of Charter, the organization has two categories of components, namely:

- main bodies (General Assembly, Security Council, Economic and Social Council, Trusteeschip Council, The International Court of Justice and the Secretariat); and

- subsidiary bodies, entities set up by main organs, with a complete delegation, made up of representatives of the Member States or specialists, with the aim of contributing to the achievement of goals and organization of its main components.

The main bodies and of a large part of the subsidiary bodies have, in accordance with Charter of the United Nations and other acts for the setting up, organization and functioning, specific powers to attain one of these purposes stipulated by the Charter, namely "promoting and encouraging respect for human rights and fundamental freedoms for all without distinction of race, sex, language, or religion".

\footnotetext{
${ }^{1}$ Raluca Miga Beşteliu and colab. - International protection of human rights. Courses notes, Edited by S.C. Universul juridic, Bucharest, 2008, pages 188-189; Tudor Tănăsescu - International protection of human rights. University course, Sitech Publishing House, Craiova, 2013 , page 41.
} 
THE CHARTER OF THE UNITED NATIONS AND INSTITUTIONAL SYSTEM FOR

THE PROMOTION AND PROTECTION OF HUMAN RIGHTS

Consideration of institutional system for the promotion and protection of human rights established by the Charter of the United Nations and in its base ${ }^{2}$.

A. Main bodies of the $U$. $N$.

a) The U.N. General Assembly

It is the most representative of the organization main body, with the most important functions and powers in the field of promoting and respect for human rights, composed of representatives of all Member States ${ }^{3}$.

The Charter of the U.N. assigned competent in the matter of human rights to General Assembly, which are concerned about the promotion and their coverage. Thus, under the Charter, the General Assembly is competent to initiate and make recommendations with a view to "supporting accused human rights and for fundamental freedoms for all without distinction as to race, sex, language or religion"4. For the fulfilment of this powers General Assembly has adopted and opened for signature, a significant number of international conventions relating to human rights, documents which have been promoted and preceded by resolutions and, respectively, of declarations of it, sometimes particularly, as well as Universal Declaration of Human Rights and the Declaration on disposal of all forms of racial discrimination. In the light of these prospective the General Assembly shall receive and examine reports sent by the other components of the United Nations with powers in the area of human rights.

General Assembly works in committees, entities which form an integral part of Assembly. In domain of human rights the most important committee is the Committee for social problems, cultural and humanitarian.

According to the Charter of the United Nations, the General Assembly may establish such subsidiary organs as it considers necessary for the performance of its functions ${ }^{5}$. In the domain of human rights, the General Assembly has created several such components, among these we mention:

- The Special Committee to examine the situation with regard to the implementation of the Declaration on the granting of independence colonial countries and peoples ${ }^{6}$, created in 1961 ;

- $\quad$ The United Nations Committee for Namibia, created in $1967^{7}$;

- The United Nations High Commissioner for Refugees created in 1950;

- The United Nations High Commissioner for Human Rights created in 1967;

- The Human Rights Council created in 2006 and so on.

\section{b) The U.N. Security Council}

It is one of the six main bodies of U.N., with limited competence and political role, which returns as main responsibility maintaining peace and international security. It is made up of 15 members of which 5 permanent and 10 elected for a period of two years.

The U.N. Security Council may decide that an international context represents a threat to peace, a breach of it or an act of aggression and, consequently, may decide on measures involving use of force to maintain or restore international peace and security.

According to The Charter of the United Nations, powers in the area of human rights they had only General Assembly, Economic and Social Council and the Trusteeship Council, as well as subsidiary bodies thereof ${ }^{8}$. Starting with the seventh decade of the XX century, in the exercise of its role in maintaining peace and international security, the Security Council decided that serious infringements, which are bulky and repeated human rights violations may constitute threats against peace ${ }^{9}$. Therefore, the Security Council adopted resolutions of condemnation of such violations, as well as for action to be taken against them.

For example policy condemnation of racial discrimination and aparheid in South Africa, as well as for non-compliance with armament embargo on, and designating as a threat to peace and security. It

\footnotetext{
${ }^{2}$ Niciu I. Marţian, International public law, Servosat Publishing House, Arad, 2004, page 230; Tănăsescu Tudor, op.cit., page 42 and International public law. University Course, Second edition revised and added, Sitech Publishing House, Craiova, 2013, page 13; Scăunaş Stelian, International law of human rights. University Course, All Beck Publishing House, Bucharest, 2003 , page 39.

${ }^{3}$ In present U.N. have 192 of states in its component.

${ }^{4}$ Art.13, point 1, letter b).

${ }^{5}$ Art. 22

${ }^{6}$ The declaration was adopted by the U.N. General Assembly Resolution No 1514/XV of 14.12.1960.

${ }^{7}$ Main function of the Committee was that of the administration of African South-Western acquisition up to its independence.

${ }^{8}$ Art. 13 part 1b, art.62 part 2, art.76 letter c).

${ }^{9}$ Resolutions 1160, 1199 and 1203, relating to the situation in Kosovo during the 1998-1999, as appears at Miga Beşteliu Raluca and colab., op.cit., p.194.
} 


\section{T. Tănăsescu}

has been claimed and taking the coercive measures, but failed due procedure veto permanent members of the Security Council ${ }^{10}$.

Also, they are to be mentioned here that the involvement of the Security Council in serious cases of breach of human rights and fundamental freedoms, which could endanger international peace and security, those which have affected Namibia (Africa South-Western) starting from the year 1969, Somalia or ex-Yugoslavia in the 1990s.

In the same plane also ranks among the reasons for the decision of the Security Council for the creation of ad hoc international criminal tribunals (the one for the former Yugoslavia and for Rwanda), who will judge abetted by natural persons of crimes committed during the genocide against humanity or of war, International facts regarded as particularly serious breaches of essential human rights ${ }^{11}$.

\section{c)The Economic and Social Council (ECOSOC)}

This is the main body of U.N which, in accordance with Charter provisions, has major tasks in promoting economic and social cooperation international, and in favoring universal and effective compliance with the human rights of any person.

To carry out its tasks increasingly circumscribes competence has been established by the Charter, namely those concerning international cooperation in economic, social, cultural, education and public health domain, including those relating to compliance with effective and universal human rights ${ }^{12}$, ECOSOC had been invested by the Charter with functions and powers as well as ${ }^{13}$ :

- initiate studies and reports on international issues in the economic, social, cultural, education, health and other related fields and may make recommendations concerning them to the U.N. General Assembly, of its members and specialized institutions concerned;

- may make recommendations, in order to promote compliance with effective and universal human rights and fundamental freedoms for all;

- may prepare draft Convention on matters within its field of competence, which it shall submit to General Assembly;

- may convene international conferences in matters within its competence;

- can coordinate the work of the specialized institutions in consultation with them, and through their recommendations to the General Assembly or of its members;

- can with authorisation by the General Assembly, to carry out the services that the members of the producer organization or specialized institutions are asking for.

For the purpose of carrying out these functions and powers, ECOSOC founded several specialized subsidiary bodies, as well as: The Human Rights Commission; The Committee on Economic, Social and Cultural Rights; The Commission on women's condition, The Human Rights Council ${ }^{14}$.

\section{d)The Trusteeship Council}

Although it has suspended its activities ${ }^{15}$ it is important to state that the Council is a main body of U.N., which is to assist General Assembly, for the purpose of carrying out its functions of the organization in respect of the arrangements for international tutelage provided for in XII chapter of the U.N. Charter. International tutelage regime has been established by the U.N. Charter for management and monitoring territories that were to be placed under this scheme under agreements which were not due to be finished until later Charter adoption. It is important to state that under the U.N. Charter one of the objectives pursued by the regime of tutelage was "to encourage respect for human rights and for fundamental freedoms for all without distinction as to race, sex, language or religion, and to develop a sense of independence of the peoples world"16.

To achieve this objective, the Trusteeship Council may fulfill the following functions ${ }^{17}$ : territories);

- examines the reports submitted to the administering authority (those responsible for managing

- receives petitions and shall examine them, in consultation with administering authority;

- organise periodic visits in the territories under the tutelage;

\footnotetext{
${ }^{10}$ Marcu Viorel, International mechanisms to guarantee the human rights, Sigma Plus Publishing House, Deva 1998 , page 108.

${ }^{11}$ Courts created by the Resolution of the U.N. Security Council No 827 of 25 May 1992 and its Resolution of the UN Security Council No. 955

of 8 November 1994.

${ }^{12}$ The U. N. Charter, art. 55, letter c) and art. 60.

${ }^{13}$ Ibidem, art.62-66.

${ }^{14}$ Details in the following sections.

${ }^{15}$ Last territory under the U.N. tutelage was the Islands Palau (South Pacific) which became independent in the year 1984.

${ }^{16}$ The U.N. Charter, art.76, letter c).

${ }^{17}$ Ibidem art.87 and 88.
} 
THE CHARTER OF THE UNITED NATIONS AND INSTITUTIONAL SYSTEM FOR

THE PROMOTION AND PROTECTION OF HUMAN RIGHTS

- it takes the action of the above, and others, in accordance with the provisions of the agreements of tutelage;

- it draws up a questionnaire concerning the inhabitants of progress territory under the tutelage (from a political point of view, economic, social and educational one) on the basis of which it shall draw up a report that is to be submitted to an annual General Assembly.

\section{e) The International Court of Justice}

It is the principal judicial main body, composed of 15 judges elected for a period of nine years by the General Assembly and the Security Council, their terms of office may be renewed. The International Court of Justice has contributed to the promotion of human rights interpretation of international standards in this area by means of both judgments (dispute between Colombia and Peru on the right of asylum, In question "Haya de la Tore" diplomatic asylum) as well as through advisory opinions (opinion at the time of the acceptance of formulation of reservations to the Convention for the prevention and fight against crime of genocide 1951, opinions on the matter is cut off of peace treaties relating to Bulgaria, Romania and Hungary, at the request of the U.N. General Assembly ${ }^{18}$ ).

Also, the International Court of Justice is designated as body of the settlement of any disputes between States Parties to numerous international treaties of human rights concerning the interpretation and application of the provisions of such substances (e.g. The Convention relating to the status of refugees - 1951; the Convention on the rights of the woman's political - 1952; the Convention on the elimination of all forms of racial discrimination in 1965; the Convention for the elimination of crime and punish apertheid - 1973, and so on).

Although the number of causes in this field solved by The International Court of Justice has been reduced, this U.N. body remains an instrument to judicial review important for Member States to settle disputes that may arise in the application of international treaties relating to human rights, to the extent that these agreements provide for such a possibility.

\section{f)The U.N. Secretariat}

The Secretariat is one of the U.N. main body which has important powers in the area of human rights. It shall be composed of the Secretary-General and the staff of the Secretariat.

The Secretary-General shall be the chief administrative officer of the U.N. appointed by the General Assembly on the recommendation of the Security Council. This, in addition to administrative role, meets and a political role and important diplomatic he acting to resolve tasks laid down by the General Assembly and the Security Council, including in the area of human rights. For this purpose the Secretary-General may use confidential offices between the Member States, better understood as well as switching of capital punishment, the release of prisoners, and so on. Also, Secretary-General may be entrusted with mandates on issues of human rights, either at the level of the Commission for Human Rights, or on the Subcommittee.

In the U.N. Secretariat during the period 1982-1997 has been running the Center for Human Rights, which is led by the Deputy Secretary-General responsible for human rights. This body, which initially was called human rights Division, have the right to support General Assembly, the Economic and Social Council, the Commission for Human Rights in the promotion and protection of the human rights and fundamental freedoms.

Following the proposals earlier in the year 1993, by its resolution of U.N. General Assembly No. 48/141 of 20 December 1993 has been set up the office of High Commissioner of the United Nations for Human Rights. The High Commissioner has rank of deputy Secretary-General, having its registered office in Geneva and a liaison office in New York. The appointment of such arbitrator shall be made by the UN General Assembly, for a term of four years with the ability to be renewed.

In the year 1997, the office of High Commissioner of the United Nations for Human Rights merged with the Center for Human Rights, resulting in High Commissioner of the United Nations for Human Rights ${ }^{19}$. This structure is headed by the High Commissioner (with rank of deputy secretary general). Between the powers of the United Nations High Commissioner also mention:

- promoting effective exercise of human rights;

- initiation of actions in the case serious violation of human rights;

- the implementation of the activities of an educational nature in favor of human rights.

\section{B. Subsidiary bodies with special powers in the area of human rights.}

\footnotetext{
${ }^{18}$ General Assembly Resolution No. 294(IV) on 22 October 1949

${ }^{19}$ Miga Beşteliu Raluca and colab., op.cit., page 207
} 


\section{T. Tănăsescu}

a) The Commission for Human Rights.

It was the most important subsidiary body for the Economic and Social Council (ECOSOC) established by that body in the year 1946, on the basis of Article 68 of the U.N. Charter. The Commission was a political body, which is made up of representatives of 53 Member States, selected after the criterion equitable geographical distribution, the mandate being of 5 years.

Since it was the main body of ECOSOC in the area of human rights, the Commission had mandate to carry out studies and reports, to provide information and other services in the human rights.

The Commission has prepared recommendations and has drawn up draft of international legal instruments in the domain of human rights.

In order to achieve these attributes the Commission has set up special working groups composed of experts and even some subcommissions on matters of human rights. Such a procedure has been applied, for example, in the case it was prepared texts of the Universal Declaration of Human Rights and international pacts of the human rights in the year 1966, when the Commission concerned and work took place on working groups. Over time, powers of the Commission were extended this being involved in most of the problems of human rights (examination of breaking human rights, analysis of breaking human rights in a given country or sector and the issue of appropriate recommendations, and so on).

For the purposes of fulfilling its tasks the Commission for Human Rights, it has created some subsidiary bodies-subcommissions.

Thus, with the authorisation of ECOSOC, the Human Rights Commission created in the year 1947 Subcommission to prevent discrimination and protection of minorities. The purpose of creating this Subcommission was to develop studies and advise the Commission for Human Rights to prevent discrimination of any kind in the exercise of human rights and fundamental freedoms and for the protection of ethnic minorities racial, national, religious and linguistic, but also in order to carry out any other tasks which may be delegated to it by ECOSOC and the Commission for Human Rights. Subcommission to prevent discrimination and protection of minorities has participated in the elaboration of some texts of the treaties of human rights and to develop procedures for their application, As well as the implementation of other documents of the U.N., such as the Declaration of the rights of people belonging to national minorities or ethnic, religious or linguistic, adopted by the U.N. General Assembly in 1992. Also, subcommission has created working groups on various issues of human rights (communication breach of human rights, contemporary forms of slavery, rights of indigenous peoples, illegal prison) and he did the same in the consideration of complaints relating to human rights violations, in accordance procedures 1235 and $1503^{20}$.

In the year 1999 the subcommission to prevent discrimination and protection of minorities, taking into account the development of its domain in human rights has changed his name, in Subcommission for the promotion and protection of human rights.

For a short period of time in the Commission for Human Rights has been created, as its subsidiary body, the Subcommission for women's condition, but in the same year (1946), the setting up, this subcommission granted the status as the Commission ${ }^{21}$.

By resolution of the U.N. General Assembly No 60/251 of 15 March 2006, it was decided to set up the Council for Human Rights ${ }^{22}$ at its head office in Geneva as part of the U.N. reform for the protection of human rights, to replace the Commission for Human Rights that subsidiary body of the U.N. General Assembly. On 16 June 2006, the Commission for Human Rights has ceased and during the period 19-30 June 2006 was carried out first session of the Council for Human Rights.

The main responsibility of the Council is to promote a universal respect for human rights and fundamental freedoms. Unlike the Commission, the Council is directly subordinated to General Assembly and has a permanent character.

The Council for Human Rights decided that in the first stage of its activity to use all of the procedures and mechanisms for monitoring compliance with human rights created the Commission for Human Rights, that in parallel to examine, to review and improve current procedures and mechanisms, based on experts and mechanisms for complaints.

\section{b) The Committee on Economic, Social and Cultural Rights}

The Committee on Economic, Social and Cultural Rights is a subsidiary body of the U.N. created by Economic and Social Council (E. C. O. S. O. C. ). Unlike the international Pact on civil and political rights, the international pact on economic, social and cultural rights in 1966 has not provided for the

\footnotetext{
${ }^{20}$ It was established by the Economic and Social Resolution No 1235 of 1967 and ECOSOC Resolution No. 1503 of 1970 , as revised in 2000.

${ }^{21}$ ECOSOC Resolution, No.11(II) on 21 June 1946.

${ }^{22}$ Bianca Selejan-Guţan, European protection of human rights. Master, C.H. Beck Publishing House, Bucharest, 2008 , page 18
} 


\section{THE CHARTER OF THE UNITED NATIONS AND INSTITUTIONAL SYSTEM FOR THE PROMOTION AND PROTECTION OF HUMAN RIGHTS}

establishment of a Committee to follow how to comply with its provisions. This shortcoming has been rectified subsequently, by the adoption of E. C. O. S. O. C. of Resolution No 1985/17 of 28 May 1985, in which it has set up the Committee on economic, social and cultural rights. The Committee has replaced the working groups created in 1976 and 1981, which had the mandate supporting E. C. O. S. O. C. in assessing progress made by States for the application of the provisions of the international Pact for economic, social and cultural rights.

The role of the Committee is to examine, on the basis of the reports submitted by Member States, the measures they have taken relating to the application of the provisions of international Pact on economic, social and cultural rights.

Reports of Member States shall be examined initially by a group made up of 5 members of the Committee which shall draw up a list of specific problems that require additional information. Then the reports are examined in plenary session by the Committee with the participation of representatives of the Member States.

At this activity, with a view to obtain additional information, it was established the practice to invite in addition to the representatives of the Member States and the specialists in the field.

Each year, the Committee shall submit to E. C. O. S. O. C. a report which shall be submitted, in brief, the debates in annual meeting of the Committee on the reports submitted by the States party to Pact and make suggestions and general recommendations to E. C. O.S. O. C. .

In the last few years, it has done for the establishment of a system of individual or collective complaints in the form of an optional protocol to the international Pact on economic, social and cultural rights.

The specific document was adopted by the Council for Human Rights and submitted for authorisation by the U.N. General Assembly.

According to the Protocol project, States parties shall recognize an opportunity for individuals to refer the Committee on economic, social and cultural rights with individual communications or group by being invoked infringements of the rights recognized in international Pact on their economic, social and cultural rights. It also recognizes the competence of the Committee to receive and analyze communication interstate agreements, subject to formulate a declaration to this effect by the State party to the Protocol.

\section{c) The Commission for women's rights}

It has been created in the year 1946 by Economic and Social Council on the basis conferred by Article 68 of the U.N. Charter. It is a subsidiary body of ECOSOC of political nature.

The powers of the Commission for women's rights have been laid down by the Economic and Social Council in its resolution on the setting up of it, and by a subsequent resolution ${ }^{23}$.

According to the specific documents, the powers of the Commission shall consist of: (a) presentation of recommendations and reports to ECOSOC regarding the development of woman's rights in the political, economic, social and education domain; (b) presentation of recommendations and proposals to the Council in connection with urgent matters on woman's rights, for the purpose of applying the principle of equal rights between men and women.

Resolutions, recommendations and other documents on which the Commission shall adopt them shall be subject to approval by ECOSOC.

In the last few years, the activities of the Commission increased significantly, the latter being involved in organization of World Conference of the United Nations for Women (1980) and in carrying out the project Convention on the elimination of all forms of discrimination against women, adopted by the General Assembly in the year 1979.

Also, with the consent of ECOSOC, the Commission has acquired and competent to receive and examine complaints relating to women's rights violation.

\section{d) The United Nations High Commissioner for Human Rights}

Setting up of the High Commissioner of the United Nations for Human Rights has been, for the first time, in the "60s", but the implementation of this idea was done much later (in 1993) by the U.N. General Assembly which by its Resolution 141/48 from 20.12.1993 to set up the function referred to. According to this resolution, the The United Nations High Commissioner for Human Rights is high official of the United Nations which has primary responsibility for the U.N. activities, in the human rights domain under the leadership Secretary -General. He is the deputy Secretary-General for human rights, provides his offices in the name of the Secretary-General, thus becoming primarily responsible for conducting activities on human rights. His mission is to promote and protect human rights in all countries

\footnotetext{
${ }^{23}$ Resolution No.11(II) on 21 June 1946 and Resolution No. 48 (IV) om 29 March 1947 (E/437)
} 


\section{T. Tănăsescu}

and to maintain a permanent dialog with them. To carry out this task the High Commissioner for Human Rights exercise more functions as regards crisis management, prevention and early warning, helping Member States in transition, promoting fundamental rights, coordination and rationalization programs relating to human rights, and so on.

After 15 September 1977, there has been created High Commissioner of the United Nations for Human Rights through the merger of High Commissioner for Human Rights Office with the Center for Human Rights, the new organism having in present the biggest responsibilities in the promotion and observance of human rights.

\section{e) The United Nations High Commissioner for Refugees}

It was set up by the U.N. General Assembly by resolution no. 428 (V) of 14.12 .1950 , starting to operate on 1 January 1951. The aim to create this subsidiary body of the U.N. General Assembly was the achievement of a better level of protection in the case international refugees.

The High Commissioner for refugees shall be elected by the General Assembly, on the proposal from the Secretary-General, the mandate being of 5 years.

The United Nations High Commissioner for Refugees has its headquarters in Geneva and several representations (offices) in countries or regions which are experiencing problems with refugees. functions ${ }^{24}$ :

To achieve the aim, the United Nations High Commissioner for Refugees meet the following

- performed international protection of the refugees through the promotion of conclusion and ratification of international conventions for the protection refugees;

- it is looking for immediate solutions on their problems, through the provision of assistance (food aid, medical, conditions for a shelter);

- provides long-term support resulted in measures concerning: any voluntary repatriation of the refugees if the conditions of the country of origin permit, naturalization in the first country of refuge and resettlement in another country, in the case in which the first country of refuge has no possibilities of assimilation.

The United Nations High Commissioner for Refugees cooperates with the U.N. and its specialized institutions and for the purpose of protection and assistance refugees, in accordance with the Treaties adopted in this domain, but also with non-governmental organizations (E.g. The International Committee of the Red Cross).

Also, the United Nations High Commissioner for Refugees collaborates with regional bodies, such as the Council of Europe.

\section{Conclusions}

- The institutional framework for the promotion and protection of human rights established by the Charter of the United Nations is part of the category of monitoring mechanisms, promotion and protection of human rights to universal level, extra-conventional control mechanisms and implementation of human rights (created in the framework of the United Nations Organization, on the basis of Charter).

- Instruments that make up the institutional system framework created by the Charter of the United Nations and in its domain in human rights are U.N. main bodies (General Assembly, the Security Council, The Trusteeship Council, International Court of Justice and the Secretariat) and a large part of the subsidiaries (The Commission for Human Rights, the Committee on Economic, Social and Cultural Rights, the Commission for Women's Rights, the High Commissioner of the United Nations for Human Rights and the United Nations High Commissioner for Refugees).

- Express Powers in the area of human rights have, according to Charter of the United Nations, only three main bodies of U.N. (General Assembly, Economic and Social Council and the Council of Trusteeship) and subsidiary bodies in their domain regarding human rights.

- In relation to their nature instruments/mechanisms forming the institutional system framework for the promotion and protection of human rights be carried out in the Charter of the United Nations are part, the exception is the International Court of Justice from the group non-judicial mechanisms (universal characteristics of the system in the protection of human rights by using procedures that state reports, reports by the control bodies, complaints about statehood, surveys and so on).

\section{Bibliography}

\footnotetext{
${ }^{24}$ Miga-Beşteliu Raluca and colab., op.cit., page 193
} 
THE CHARTER OF THE UNITED NATIONS AND INSTITUTIONAL SYSTEM FOR

THE PROMOTION AND PROTECTION OF HUMAN RIGHTS

1. Beşteliu Raluca Miga and colab., International protection of human rights. Courses Notes, Universul juridic Publishing House, Bucharest, 2008

2. Marcu Viorel, International mechanisms to guarantee the human rights, Sigma Plus, Deva, 1998

3. Selejan-Guţan Bianca, European Protection of Human Rights. Master, Ed. C.H. Beck Publishing House, Bucharest, 2008

4. Niciu I. Marţian, Public international law, Servosat Publishing House, Arad, 2004

5. Scăunaş Stelian, International law of human rights. University Course, All. Beck Publishing House, Bucharest, 2003

6. Tănăsescu Tudor, International law of human rights. University Course, Sitech Publishing House, Craiova, 2013

7. Tănăsescu Tudor, Public international law. University Course, Second edition revised and added, Sitech Publishing House, Craiova 2013 